$\because \quad 7$

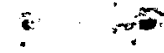

.

APF 221960
MASTER

\section{TID- 5750}

THE USE OF A FLUIDIZED BED REACTOR FOR

THE CONTINUOUS PRODUCTION OF URANIUM TRIOXIDE 
The Use of a Fluidized Bed Reactor for

the Continuous Production of Uranium Trioxide

by:

W. C. Philoon

E. F. Sanders

W. T. Trask

Introduction

Uranium trioxide is an important intermediate in the production of high purity uranium metal as conducted in such plants as that operated for the AEC by Mallinckrodt Chemical Works at Weldon Spring, Missouri. Currently this step consists of the thermal decomposition of a uranyl nitrate hydrate in gas fired, stirred, stainlesssteel pots. The pots are filled with the molten salt, heated and stirred until uranium trioxide is formed according to equation (1).

$$
\mathrm{UO}_{2}\left(\mathrm{NO}_{3}\right)_{2} \cdot \mathrm{nH}_{2} \mathrm{O} \rightarrow \mathrm{UO}_{3}+2 \mathrm{NO}_{2}+1 / 2 \mathrm{O}_{2}+\mathrm{HH}_{2} \mathrm{O}
$$

Where $n$ is usually between 3 and 4 .

The warm $\mathrm{UO}_{3}$ powder is then removed from the pot by a vacuum transfer system and the cycle is repeated. A large number of pots is used and each repeats the cycle several times a day.

The desirability of a continuous method 18 suggested by difficulties inherent in the present process. The material is heat sensitive during denitration, so that poor agitation and overheating may result in the formation of large amounts of undesirable $\mathrm{U}_{3} \mathrm{O}_{8}$. The resulting batch-to-batch variations in the product are apparently responsible for a number of operating difficulties in subsequent steps. In addition, the possible exposure of the operators to uranium oxide dust presents a formidable potential health problem. 
The experimental program described here had ae its objective the development of a low-cost continuous process for the production of a uniform uranium trioxide from purfified uranyl nitrate solution. The work was dane in the pilot plant of the Malinckrodi Uranium Divigion under contract to the Atcmie Energy Commssion.

The fluidized bed technique was aelected for severai reasona:

1. The highly turbulent mixing of golids in guch a bed insures uriform temperatire with conaequent ease of temperature control.

2. The good heat transfer characteristice and the utility of internal heating surfaces permit high production capacity in economicallysized equiprent.

3. A fluidized bed delivere a free-flowing product of high bulk deriticy outable for subaequent process steps.

4. A fluidized bed fs a clozed system with no moving parts and thus would minimize the possibility of personnel exposure to dust.

In this process the molten uranyl nitrate hydrate is continuously atomized inco a heated fluidized bed of uranlum trioxide particles where evaporation and thermal decompostion cccur. The resulting solld $\mathrm{HO}_{3}$ product 18 withdrawn continuously.

The use of aluidized bed for the thermal decomposition of uranyl nitrate was first investigated by Argonne Netional Laboratory $(1)_{u s i n g}$ a six-inch diameter reactor. Heat was supplied by tubular electrical heatesa set in grooves in the reactor wall, the bed was fluidized with air, and the uranyl nitrate solution was introduced through a two fluid atomizing spray nozzle in the reactor wall. Production rates as high as 100 pounds $\mathrm{UO}_{3}$ per hour per square foot of cross sectional axe were achieved. 
Since the production rate lo limfed by the heat input abllity of the reactor, a different heating technique was required to achieve high production rates in a larger reactor, as the surface-to-volume satio decreases with larger reactor diameter. The use of internal heat transfer surface was therefore studied in the present work.

The first ten-inch diameter fluidized bed reactor built in the Mallinckrodt pilot plant used the Argonne principles except that heat was applied to the bed internally as well as externally. ${ }^{(2)(3)}$ There were 70 , one ohalf inch diameter by one foot long electrical heaters protruding through the gas distribution plate into the reaction bed. Several months of operating experience with this unit provided information for the design of an improved ten-inch diameter unit.

The principal difficulty experienced was with the electric heaters. Any mis. operation or instablity in fluldization caused high heater-element ourface temperatures, resuleing in the formation of $\mathrm{U}_{9} \mathrm{O}_{8}$ and frequent burn out of the heaters. A more readily controlled means of heat input was therefore sought.

\section{Equipment Description}

The present reactor, shown in figure 1, consists of a ten-inch diameter type 347 stainless steel pipe, six feet long, with a twenty-inch diameter disengaging section located on top of the reactor and fluidizing gas distribution plate flanged to the bottom.

Th1rty, one and one-quarter inch diameter bubble-cap-type distributors are provided in this plate with one-inch diameter bayonet heater passing through each bubble-cap and extending three feet into the reaction bed. Figure 2 shows 
a detail of one of these bubbleacaps. Fluddizing air from the supply chamber below the distributor plate passes through the annular space between the bubblecap and the bayonet heater and then into the reaction bed through three holes equally spaced around the riser just under the cap.

Heat is suppiled to the reaction bed by molten heat transfer salt (45\% sodium nitrite, $55 \%$ potassium nitrate) circulating through the bayonet heaters. As seen In Figure 1, the hot salt enters a supply chamber directly below the fluidizing gas chamber and passes through the annular space between the one-inch diameter outer tube and the 5/8-inch diameter inner tube, then returning through the inner tube and out the digcharge chamber below the supply chamber.

Molten uranyl nitrate hydrate is eprayed into the reaction bed through a two fluld atomizing nozzle mounted $s$ ix inches above the tops of the heaters. A section of this nozzle is show in Figure 3. The molten uranyl nitrate passes through the central orifice and is atomized by air flowing through the annular orfice. The nozzle is installed with the tip flush with the inside of the reactor wal1.

Figure 4 shows the fluidized bed unit with air is metered through an electrical preheater to the gas distributor supply chamber. The molten uranyl nitrate hydrate is tapped from a recycle loop and metered through a rotameter to the spray nozile. Air for atomization is also metered by a rotameter.

The heat transfer salt is heated by electrical imeersion heaters in a large steel pot and pumped to the reactor by a vertically mounted, submerged centrifugal pump, driven by a 7.5 horsepower D.C. motor. The speed of the motor is controlled by the reactor temperature in the spray zone. 
The $\mathrm{NO}_{3}$ product overflows from the reactor through a two-inch diameter pipe, four and onemalf feet from the bottow of the bed, through a surge hopper and a rotary valve into a packaging station. The off-gases leave the reactor through a two-inch pipe at the top of the disengaging section and pass through a cyclone separator to a scrubber; dust removed by the eyclone falls into a hopper whence It returns to the reactor through a rotary valve.

\section{Operating Conditions}

The operating conditions selected for the experimental investigation are summarlzed in Table I. The reactor has been operated at temperatures ranging from $600^{\circ} \mathrm{F}$ to $800^{\circ} \mathrm{F}$. Operation of the unit below $600^{\circ} \mathrm{F}$ has been prevented by condensation of the reaction gases in the offogas piping and wet powder plugging the fines refeed system. Operation at temperatures sbove $800^{\circ} \mathrm{F}$ restricted the capaclty of the unit, ince for afety reasons the temperature of the heat tranafer salt was 1 imited to $1000^{\circ} \mathrm{F}$.

Preheated alr was used as the fluidizing medium at flow rates ranging from 16.5 to 20 standard cublc feet per roinute. The flow rate was varied with the bed temperature to maintain a constant fluldialng gas velocity at the bottom of the reactor.

The urany 1 nitrate-was fed to the reactor in concentrations ranging from five pounds of uranium per gallon to the molten uranyl nitrate trihydrate containing approximately cwelve pounds of uranium per gallon. The initial experimental work was done using an aqueous solution of uranyl nitrate with a freezing point of $70^{\circ} \mathrm{F}$ (about $5 \mathrm{lbs}$. U/gal) to simplify the handling and metering equipment. Even though the handling and metering problems with molten uranyl nitrate

$$
\text { bก }
$$


hexahydrate (which freezes at $140^{\circ} \mathrm{P}$ ) and uranyl nitrate trihydrate (which freezes at $230^{\circ} \mathrm{F}$ ) are more complex, later work was done using the high feed concentratlons to take advantage of the higher productivity and the decrease in the quantity of reaction gases.

A single atomizing nozzle was used to introduce the feed liquor into the reaction bed. The liquid feed rate through the nozzle was varied between 6 and 13.5 gallons per hour using atomizing air flows ranging from 0.8 to 3.6 standard CFM at 10 to 60 PSIG.

Production rates of 50 to 150 pounds $\mathrm{UO}_{3}$ per hour have been attained in this unit; the lower rates with dilute aqueous feed concentrations and the higher rates with the molten uranyl nitrate hydrates. At rates higher than 150 pounds per hour, quantities of uranyl nitrate were carried out of the reaction bed which resulted in clogging of the off agas system.

There is an abrupt change in fluidizing velocity at the top of the heater tubes resulting from the sudden increase in free cross section area. The average superficial velocity of the fluidizing gas in the heater zone is $1.7 \mathrm{ft} / \mathrm{sec}$ and drops to a value of $1.25 \mathrm{ft} / \mathrm{sec}$ in the spray zone. Under the operating conditions employed, the gases evolved in the reaction are approximately equal in volume te the fluidizing gas, however, and since most of the reaction probably occurs in the spray zone, there is a net increase in total gas velocity above the heater tubes. Thus, the restricted free area in the bottom section causes high gas velocity promoting good heat transfer, while the expansion of area in the spray zone prevents gas velocity high enough to cause severe elutriation. 


\section{TABLE I}

\section{Fluidized Bed Operating Conditions}

\begin{tabular}{|c|c|c|c|c|c|c|c|c|c|c|}
\hline Run Number & 1 & 2 & 3 & 4 & 5 & 6 & 7 & 8 & 9 & 10 \\
\hline Reactor Temperature, ${ }^{\circ} \mathbf{P}$ & 810 & 705 & 735 & 600 & 630 & 625 & 615 & 635 & 595 & 600 \\
\hline $\begin{array}{c}\text { Fluidizing Air Flow Rate, } \\
\text { Standaxd CFM }\end{array}$ & 16.5 & 18 & 18 & 20 & 20 & 20 & 20 & 20 & 20 & 20 \\
\hline $\begin{array}{l}\text { Uranyl Nitrate Feed Concentration, } \\
\text { lbs. U/gal }\end{array}$ & 7.7 & 6.8 & 6.8 & 6.8 & 5.0 & 5.0 & 10.0 & 10.0 & 12.0 & 11.5 \\
\hline Usanyl N1trate Feed Rate, gal/hr & 6.7 & 6.0 & 9.4 & 6.0 & 9.1 & 13.5 & 7.8 & 8.4 & 9.7 & 11 \\
\hline Atomizing Aix Flow, Standard CFM & 1.5 & 1.5 & 0.8 & 0.8 & 1.5 & $0: 8$ & 1.0 & 1.3 & 3.6 & 0.8 \\
\hline Atomizing Alr Pressure, psig & 60 & 35 & 50 & 10 & 30 & 35 & 50 & 50 & 50 & 55 \\
\hline Production Rate, $1 b_{s} . \mathrm{wO}_{\mathrm{g}} / \mathrm{hx}$ & 63 & 50 & 78 & 50 & 57 & 80 & 95 & 100 & 140 & 150 \\
\hline
\end{tabular}




\section{$\underline{\text { Results }}$}

The uranium trioxide product was a free-flowing granular material made up of essentially spherical particles, visually similar to those produced in the continuous trough calciner described by Szulinski. (5) The assay of the product averaged 99.0 percent $\mathrm{UO}_{9}$ with residual nitrate and water content consistently less than one percent. There was no evidence of the intermediate oxide, $\mathrm{U}_{3} \mathrm{O}_{8}$, formation in any of the runs.

The reactor operating conditions had a pronounced effect on the particle size of the product. Figure 5 shows the effect of the operating temperature on the average particle diameter. The average particle size produced at $700^{\circ} \mathrm{F}$ was $2-1 / 2$ times greater than that produced at $600^{\circ} \mathrm{F}$. At an operating temperature of $800^{\circ} \mathrm{F}$ the average particle size of the product continued to increase until loss of fluidization occurred. This temperature effect on the particle size is not yet fully understood, but it may be postulated that, since at a given superficial fluidizing velocity there 18 a higher bed vold fraction at higher temperature, there are fewer solid particles on which the liquid droplets may collect, thus causing more rapid growth and hence larger particles.

Figure 6 shows the effect of the nozzle operation on the average particle size of the product. As the ratio of the volume of atomizing air to volume of liquid feed through the nozzle is decreased, the average particle size of the product increases. This observation suggests that the particle size of the product is related to the degree of atomization at the nozzle. 
Both the feed liquor concentration and flow rate seem to affect the particle size of the product, probably because they affect the volume of gas generated and hence the quality of fluidization in the spray zone. The average particle size of the product was correlated with the total gas flow in the spray zone and the operating temperature as shown in Figure 7 . The temperature used in this smpixical correlation is in the form of denitration driving force. These data suggest that increased turbulence and attrition occurring at the higher gas flows result in a smaller average particle size in the product.

The product had a high bulk density, ranging from $3.5 \mathrm{gms} / \mathrm{cc}$ to $4.3 \mathrm{gms} / \mathrm{cc}$ depending on the production rate as shown in Pigure 8 . It should be pointed out that the data employed to develop this curve were not obtained at a constant feed concentration, ince during operation at the higher rates a considerably higher feed concentration was employed than at the lower rates. The higher rates and/or feed concentrations may result in increased voids within the particles and consequently a lower bulk density. Particle size distributions were almost identical at different production rates in a number of cases, Indicating that the distribution is not a factor in the bulk density change.

Photomicrographs of the particles produced at a low feed concentration and rate and the high feed concentration and rate are shown In Flgure 9. Apparently the mechanism of particle formation is different at the two conditions. The laminar particle formed during a run using a dilute aqueous feed at a low production rate suggests that the atomized liquid droplets deposit on the fluldized solid particles prior to decomposing. In the case of the highly concentrated feed liquor at high rates it appears that the mechanism changed to 
primarily one of agglomeration of the liquid droplets or fine solid particles since no laminations are visible.

The heat input to the fluidized bed ranged from approximately $72,000 \mathrm{BTU} / \mathrm{hr}$ to $160,000 \mathrm{BTU} / \mathrm{hr}$. Table II shows the apparent overall heat transfer coefficients for the runs made at a nominal $600^{\circ} \mathrm{F}$ operating temperature. These data indicate that the heat transfer improves with increasing production rate with the exception of the anomalous result reported for Run Number 7. A comparison of the overall coefficient between $600^{\circ} \mathrm{F}$ and $700^{\circ} \mathrm{F}$ operating temperature at equivalent production rates is shown in Table III.

Since the purity requirements for uranium products are very high, any corrosion of the fluidized bed untt would be of serlous concern in the denitration reaction. Iron pickup in these runs has consistently been less than $20 \mathrm{PPM}_{2}$ however, and is not considered significant.

\section{Conclusions}

A fluid bed reactor has been demonstrated to be a reliable and flexible device for continuously producing UO $_{3}$ from uranyl nitrate.

Internal heat transfer tubes occupying one-third of the reactor crose section permitted a production rate of 300 pounds of $\mathrm{UO}_{3}$ per hour per square foot of bed cross section and should allow direct scale-up to commerclal-8cale dimensions.

Chemical purity of the product $\mathrm{UO}_{3}$ was excellent, and its physical properties could be controlled by variation of operating conditions. 
Page 11

TABLE II

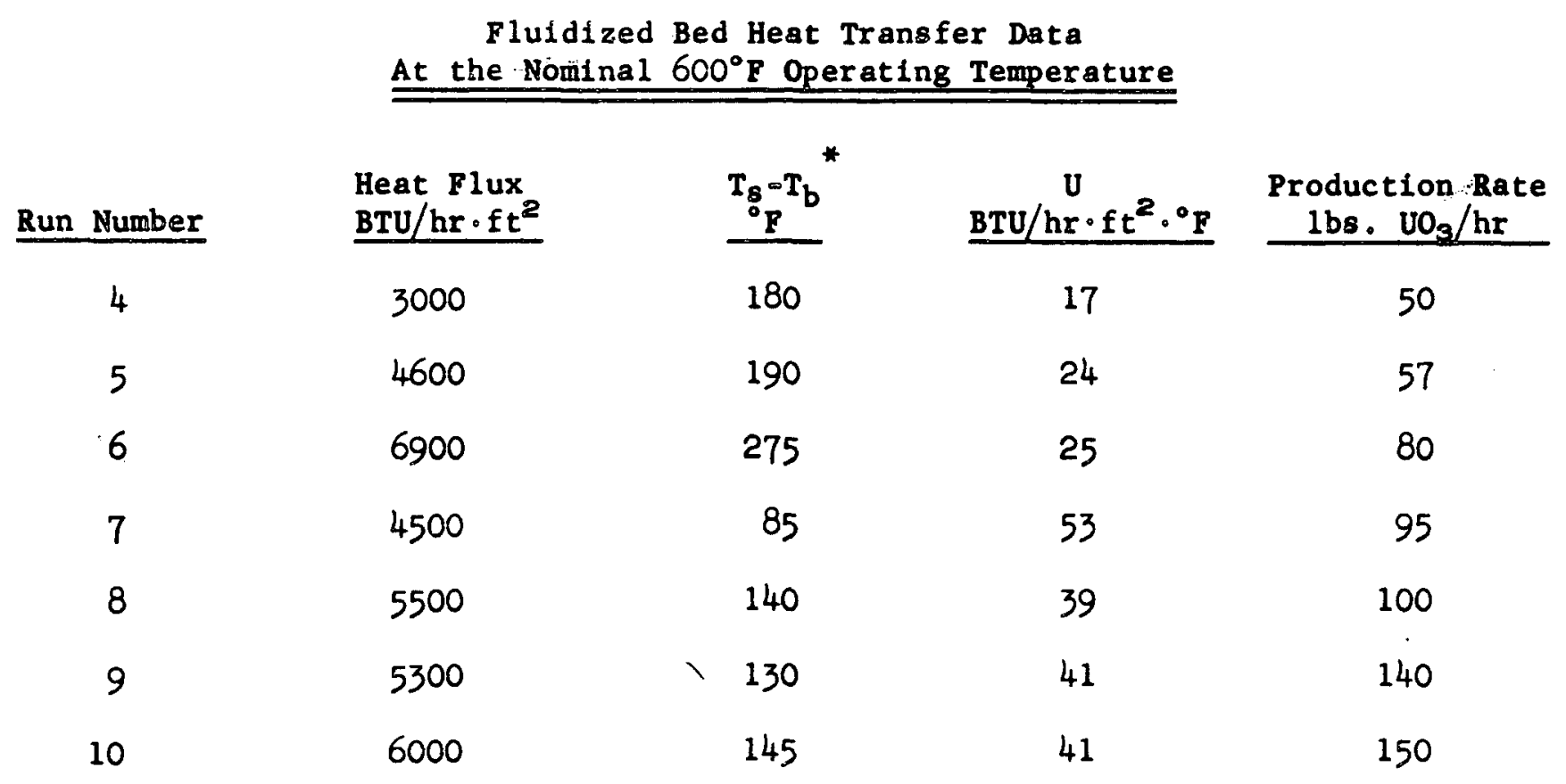

\footnotetext{
* $T_{8}=$ Average Molten Salt Temperature.

$\mathbf{T}_{\mathrm{b}}=$ Average Fluld Bed Temperature。
} 


\section{TABLE III}

Fluidized Bed Heat Transfer Data At $600^{\circ} \mathrm{F}$ and $700^{\circ} \mathrm{F}$ Operating Temperatures

\begin{tabular}{|c|c|c|c|c|c|c|}
\hline Run & Number & $\begin{array}{l}\text { Heat Flux } \\
\text { BTU/hr } \mathrm{ft}^{\mathrm{z}} \\
\end{array}$ & 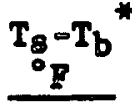 & 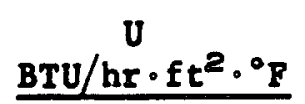 & $\begin{array}{l}\text { Operating } \\
\text { Bed Temp. }{ }^{\circ} \mathrm{F}\end{array}$ & $\begin{array}{c}\text { Product } \\
\text { Rate } 1 \mathrm{bs} / \mathrm{hr} \\
\end{array}$ \\
\hline & 2 & 3200 & 23.0 & 14 & 700 & 50 \\
\hline & 4 & 3000 & 180 & 17 & 600 & 50 \\
\hline & 3 & 5000 & 280 & 18 & 700 & 78 \\
\hline & 6 & 6900 & 275 & 25 & 600 & 80 \\
\hline
\end{tabular}

* $T_{8}=$ Average Mclten Salt Temperature.

$T_{b}=$ Average Fluid Bed Temperature. 


\section{References}

(1) Jonke, A. A., et.al., Argonne Natlonal Laboratory, U.S. A.E.C. Report, TID-7501, (Pt. 1), February 1956, p. 53-72.

(2) Sanders, E. F. and Robinson, S. N., Bluid Bed Denitration, Process Development Quarterly Report, U.S. A.E.C. Report, MCW-1409, Mallinckrodt Chemical Works, November 1, 1957.

(3) Sanders, E. F., et.al., Fluid Bed Denitration, Process Development Quarterly Report, U.S. A.E.C. Report, MCW-1411, February 1, 1958.

(4) Damerval, F. B., et.al., Fluid Bed Denitration, Process Development Quarter1y Report, U.S. A.E.C. Report, MCW-1421, November 1, 1958.

(5) Szulinski, M. J., Chemical Engineer1ng Progres8, 53, p. 586-589, (1957). 


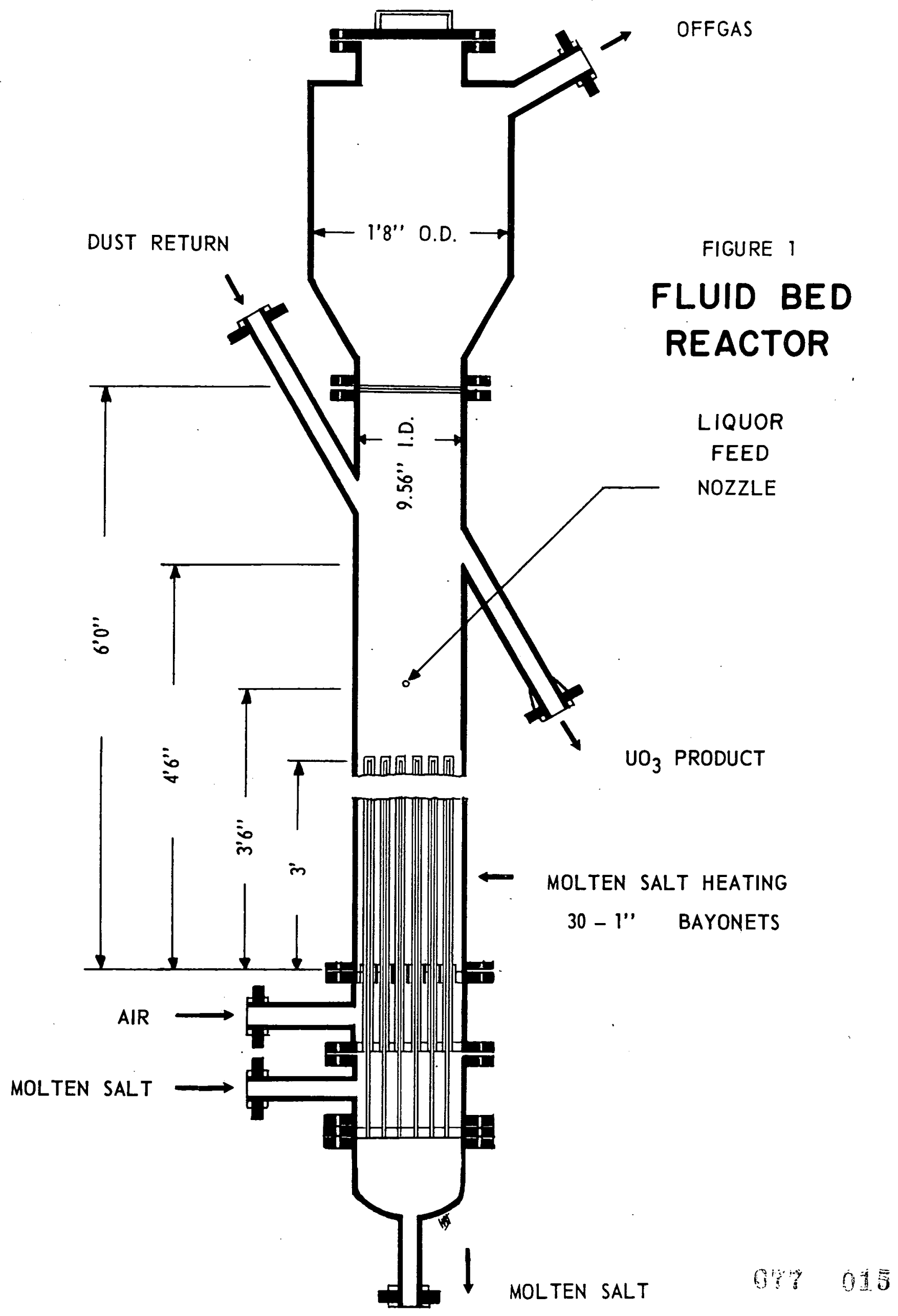




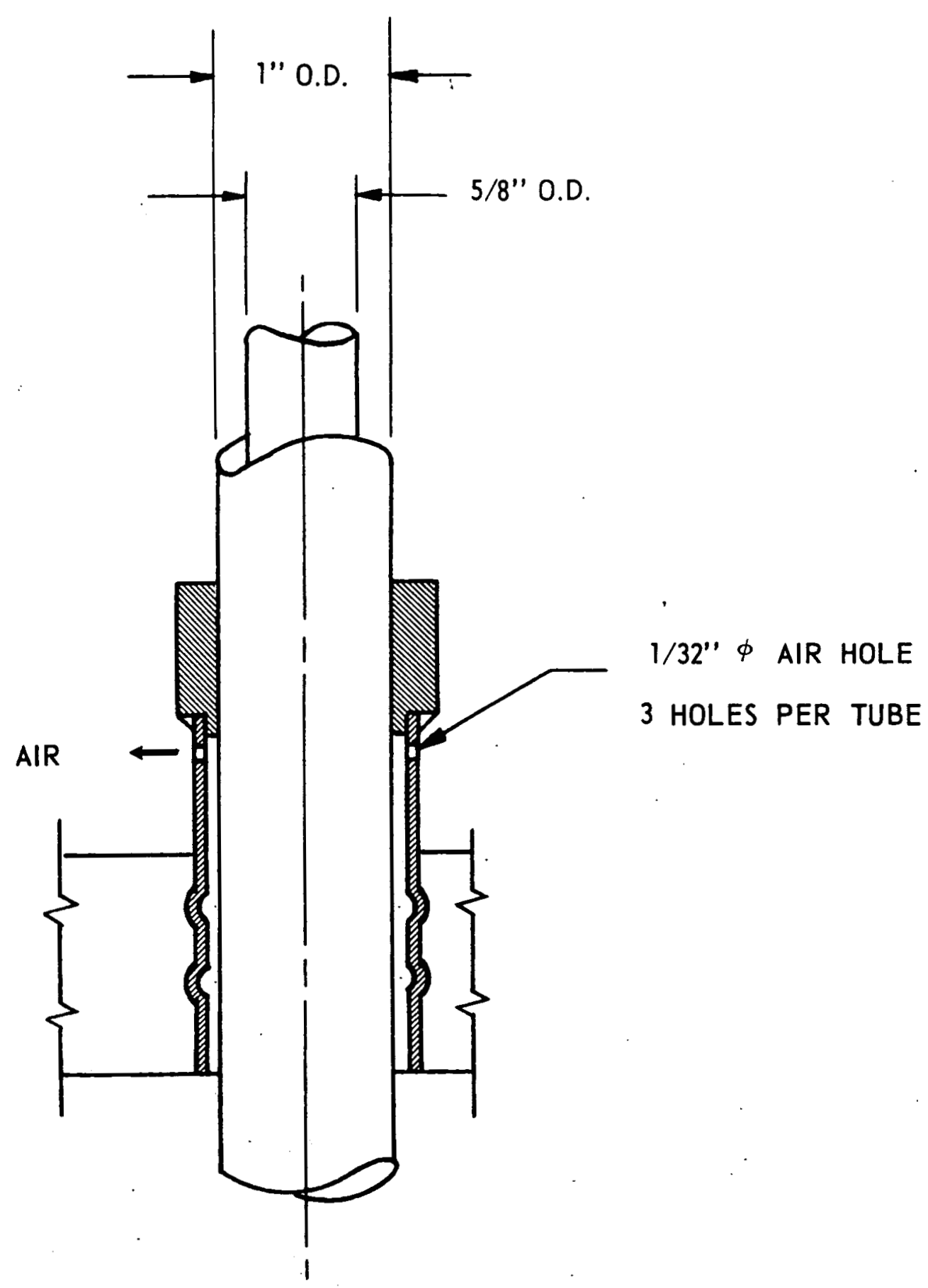

FIGURE 2

DISTRIBUTION PLATE DETAIL 
FIGURE 3

FEED NOZZLE

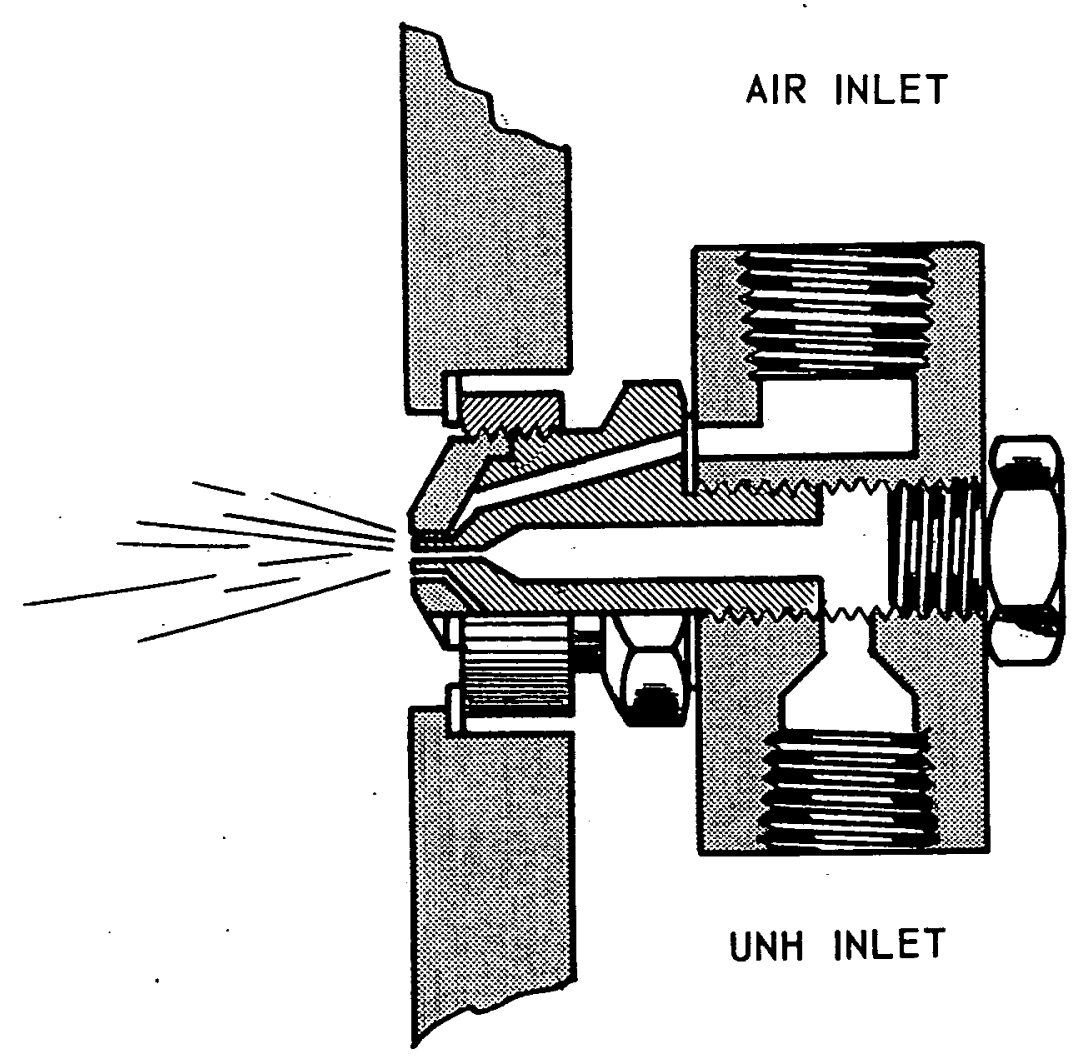

REACTOR WALL 
FIGURE 4

FLUID BED DENITRATOR

U

FROM URANYL NITRATE SUPPLY
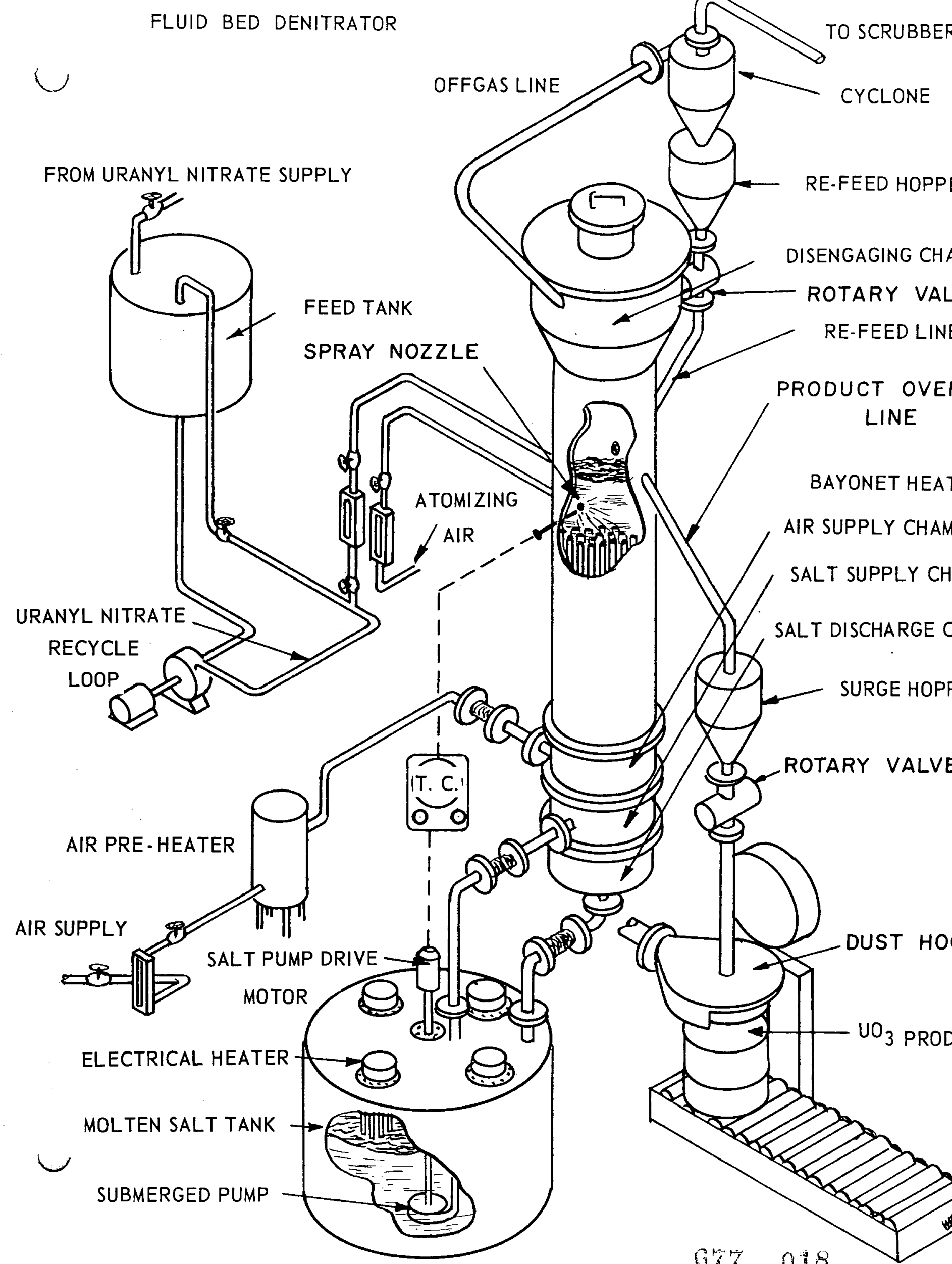


\section{Figure 5}

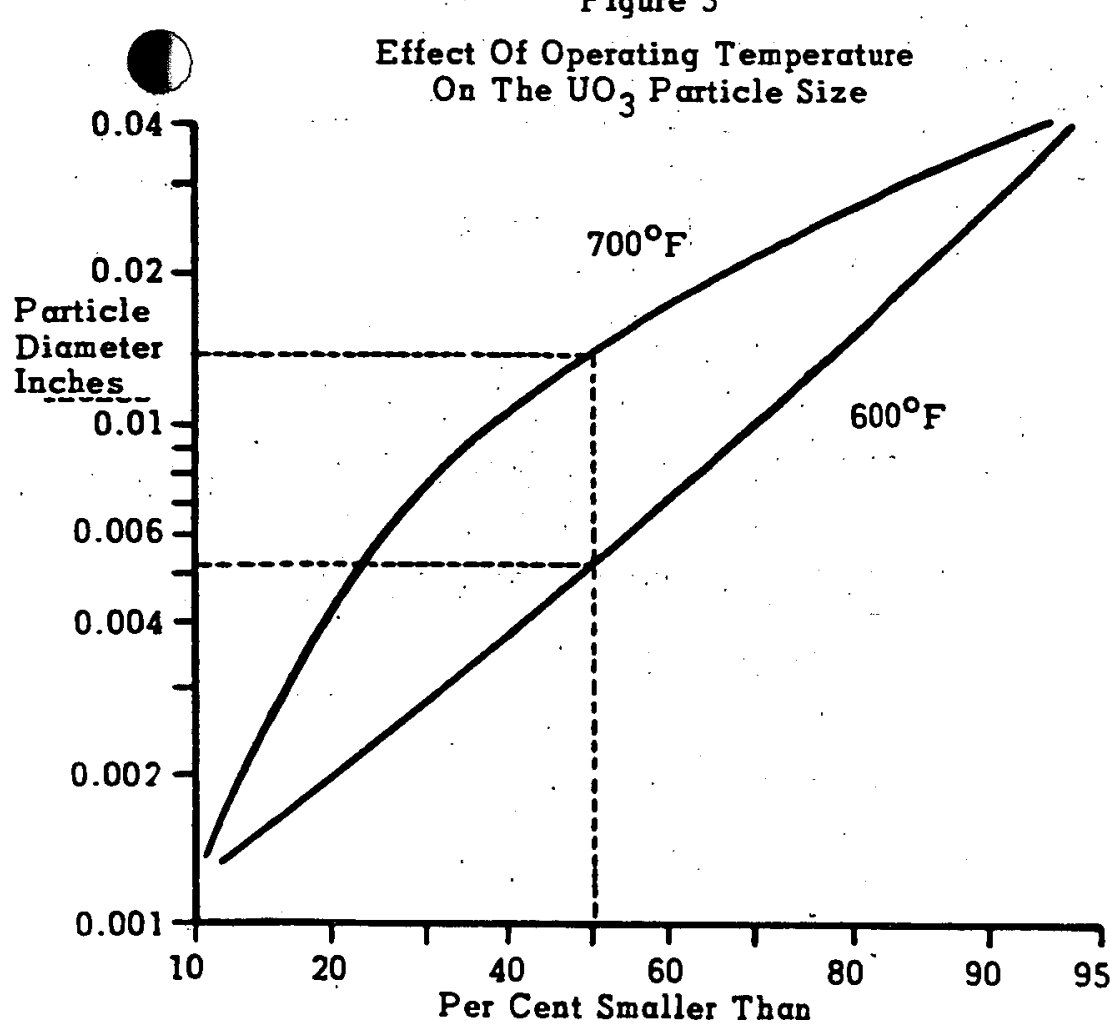

\section{Figure 6}

Effect Of Atomizing Air To Feed Liquor Volume Ratio On The $\mathrm{UO}_{3}$ Particle Size

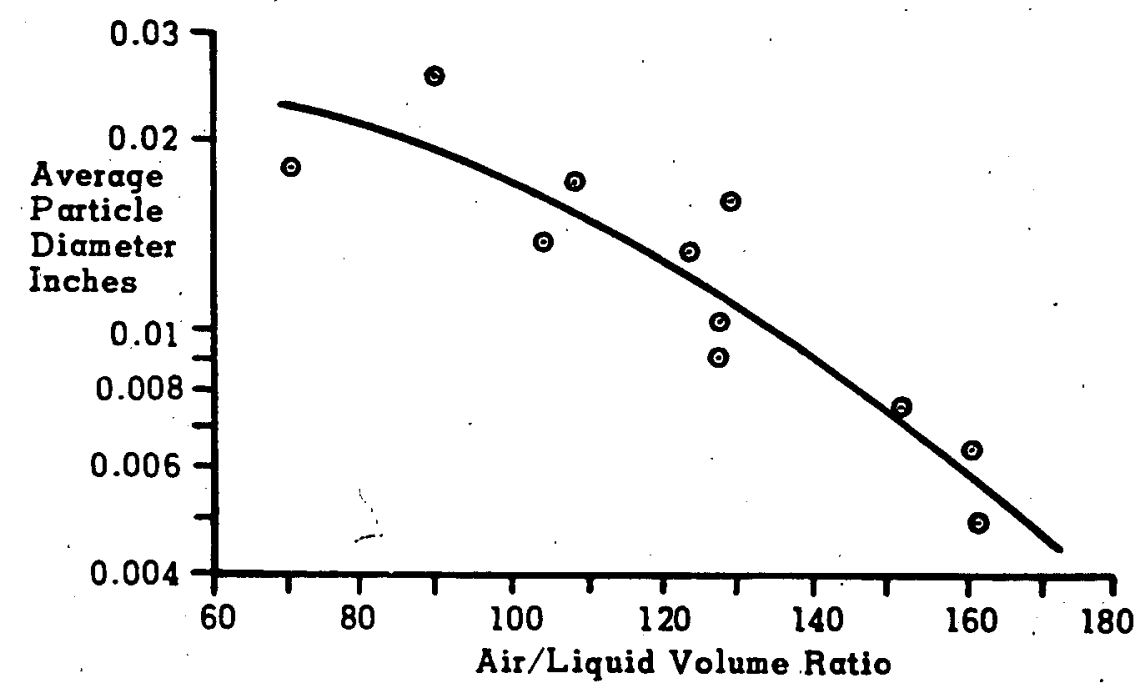

Figure 7

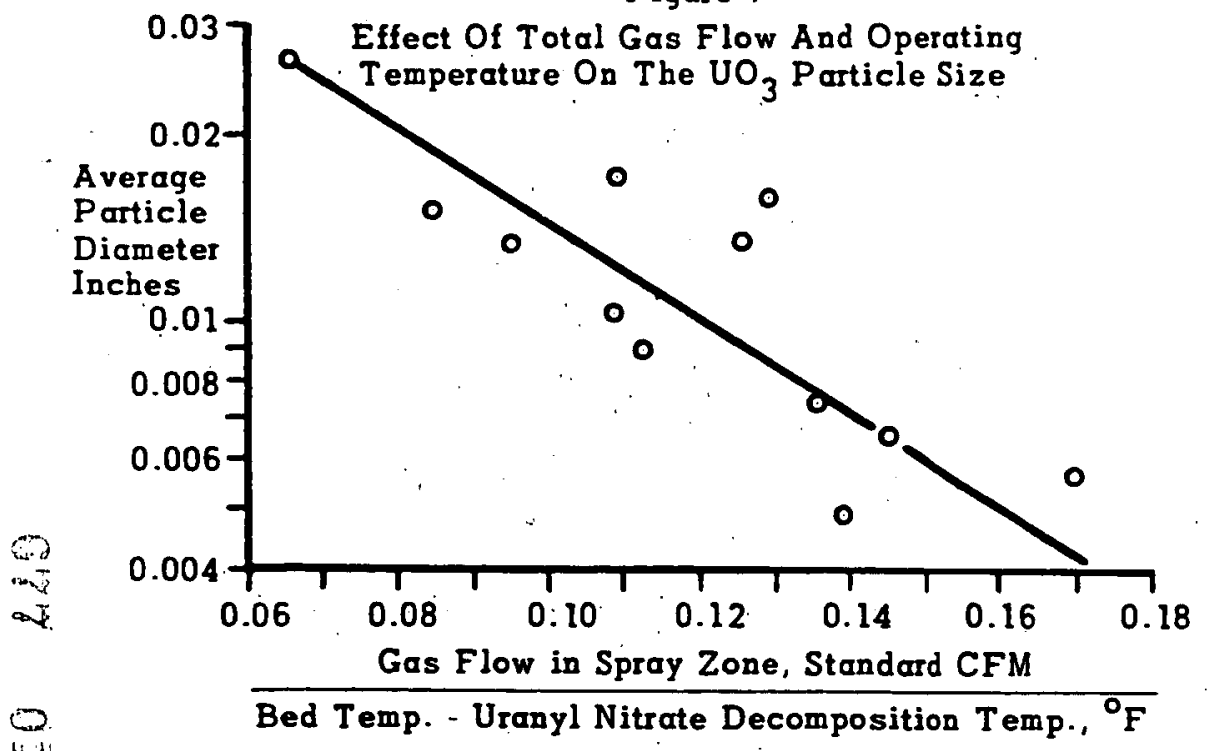

Figure 8

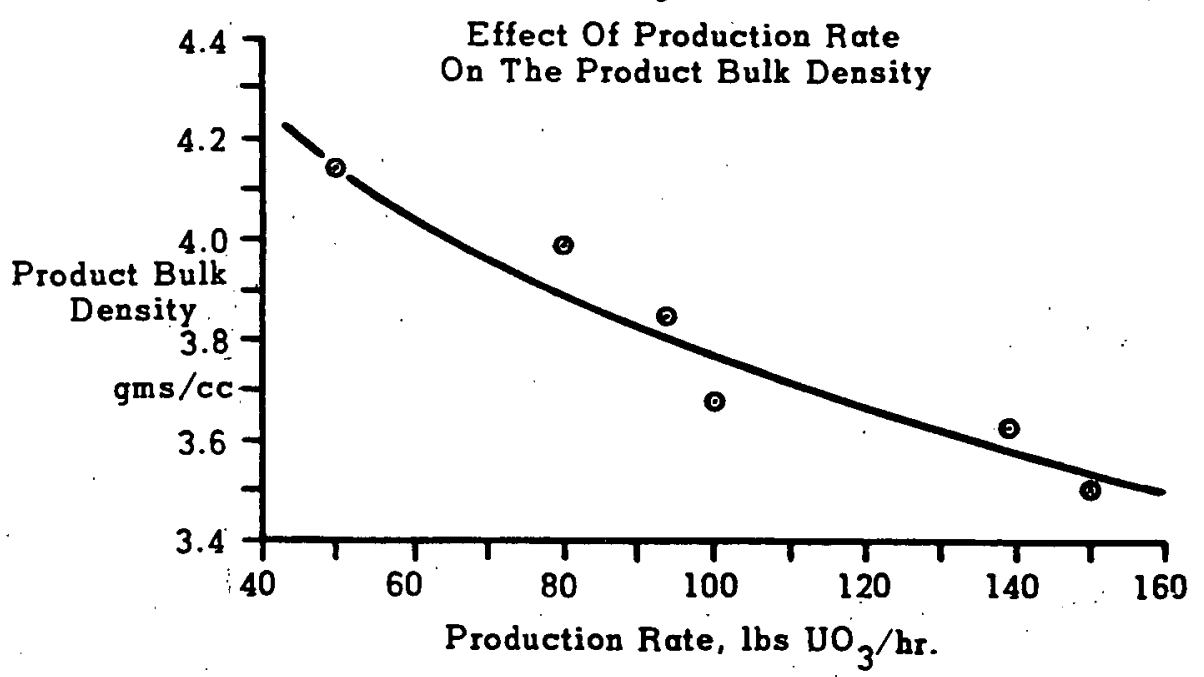




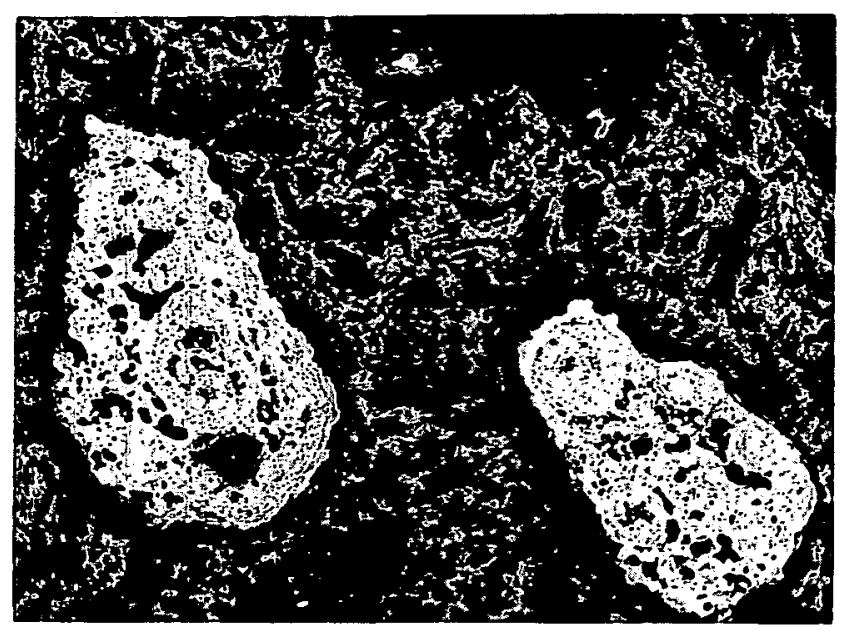

(a) Agglomerate particles, $100 \times$

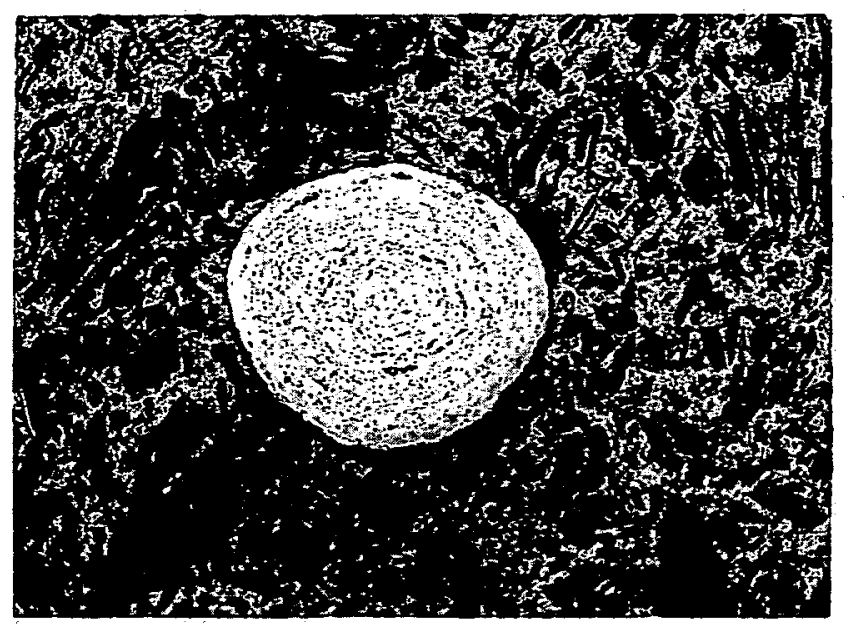

(b) Laminar particle, $100 x$

PIgure 9. Fluld Bed $\mathrm{UO}_{3}$ 